\title{
Design and Development Paper Printout System for Gardu Tol Otomatis (GTO) based on Mechanical Approach
}

\section{Gatot Suharjanto ${ }^{1}$, Khristian Edi Nugroho Soebandrija ${ }^{2}$, Erwin Rezasyah ${ }^{2}$, and Novita Sakundarini ${ }^{3}$}

${ }^{1}$ Architecture Department, Faculty of Engineering, Bina Nusantara University, Jl. K. H. Sudan No. 9, Kemanggisan, Palmerah Jakarta 11480 Indonesia

${ }^{2}$ Industrial Engineering Department, Faculty of Engineering, Bina Nusantara University, Jl. K. H. Syahdan No. 9, Kemanggisan, Palmerah Jakarta 11480 Indonesia

${ }^{3}$ Department of niversity of Mechanical, Materials and Manufacturing Engineering, University of Nottingham Malaysia, University, Jalan Broga, 43500 Semenyih, Selangor, Malaysia

\section{Abstract}

The existence of Gardu Toll Otomatis (GTO), automatic toll payment, becomes a general model for every toll payment in Indonesia. Almost toll payment models in Indonesia have a paper printout as received which is often wasted. This condition

Corresponding Author: Gatot Suharjanto

Gatotsuharjanto@binus.edu

Received: 16 February 2020 Accepted: 5 March 2020

Published: 10 March 2020

Publishing services provided by Knowledge

(c) Gatot Suharjanto et al. This article is distributed under the terms of the Creative Commons Attribution License, which permits unrestricted use and redistribution provided that the original author and source are credited.

Selection and Peer-review under the responsibility of the ICLBI (2018) Conference Committee. happens since not all the driver needs a paper proof of the transaction. Therefore, the wasted paper will occur everywhere for $24 \mathrm{~h}$. Furthermore, in this work the design of printout system using a more efficient printout model with rotation feeding method has developed printout system. In this work, the rotation mechanism system is applied through product design engineering through Industry 4.0. This system is made by removing the printout paper that remains present to the driver who needs it, but not wasted because of the driver who does not need it. There are three important steps as follows; in the first step, the printout paper appears in a special tray which is easy to reach and takes for those who need it. In the second step, the paper will remain in the tray for the driver who did not pick it up and final step, the tray with paper printout will rotate mechanically back into the GTO machine to be destroyed by a paper shredder. The experiment of the paper printout system has been carried out. The results show that the proposed approach produces a better accuracy and efficiency. Experimental results show the testing accuracy of $90 \%$. The system confirms the effectiveness of the proposed paper printout system for the GTO.

Keywords: Digital technology; digital transformation; electronic banking; online payment; electronic wallet.

\section{Main text}

Digital technology plays important role in nowadays advance developed technology. One of the emerging technologies is Internet of thing (IOT) which is one of the main key 
machine (ATM), Electronic Banking (E-Banking), Mobile Banking (M-Banking), Electronic Money (E-Money), Online payment, Electronic Wallet etc., are also rapidly used as a trading transaction nowadays. Currently, the electronic payment receipt or electronic receipt (e-receipt) is also starting to become more popular to be the evidence of the trading transaction. A private company in the UK has been providing e-receipts in Europe since 2009 [2]. E-receipt integrates with data collection systems in various companies. As a result, not only the environments rescued by the reduced use of paper for conventional receipts, but also benefits the consumer, the agency where the consumer works, and the provider of the e-receipt itself, since the budget of providing the paper to print the receipt of the transaction is reduced significantly. However, in many developing countries such as Indonesia, the paper payment receipt still became the main form of the payment evident in many transactions.

The implementation of the paper payment received is also applied in automatic toll gate. The customer will reduce the amount of money automatically from the customer card. There are many advance technologies applied in the Highway Automatic Gate, such as, RFID technology and the payment through social messenger [3], the RFID technology also applied for the toll gate and GSM technology [4]. However, the use of paper as payment receipt still became very popular in many trading transactions. In Indonesia the conventional payment received, such as paper still become a popular and high demand in trading transactions [5]. Therefore, in the future the conventional payment received are still becoming primary popular and usable. The same thing also happens in the payment activity of highway usage in general in Indonesia. Although the era of e-money has been applied nationally, the transaction proof process still remains a paper structure.

Based on the interview with an Indonesia highway officer, there are several model and transaction systems have been proposed. However, not all the highway users have the same need. Generally, the proposed of technology capable to produce electronic receipts still cannot be applied, since not everyone has a personal special bank account, even many people still do not have a bank account at all. Ideally, if the whole community has at least one bank account number and integrated with the electronics citizenship card, such as (e-KTP card). This e-KTP known as Kartu Tanda Penduduk, translated as National Citizen ID, then this can already be integrated with all types of transactions.

The use of the electronics-toll card (e-toll card) or electronic money (e-money) is one of the simplest transaction solutions to be used in this era of electronic transactions [6]. In this transaction the owner of the e-money card does not have to be owned 
by people with only bank accounts, but also for people who do not have any bank account. Therefore, the e-money system was designed to require no integration of card data with the card owner at all, consequently no transaction information can be sent to the cardholder electronically. This is the real condition why the transaction receipt still exists as one of the proofs of legitimate transactions. Due to that reason, the payment received in automatic highway Gate (GTO) is still based on paper [4]. Therefore, it is important to design GTO machine in the such way that, the minimize the payment received to be wasted.

\section{Problem statement}

Problems arising from the system of providing a paper payment receipt as a physic evident of every transaction. Therefore, a paper payment evident are always generated in every highway automatic gate (GTO). This condition is resulting in the waste paper payment of the substation machine which is not fully needed and taken by the rider, so the paper payment evident to be scattered at any time for $24 \mathrm{~h}$. This condition results by many paper blows in the road, as shown in Figure 1.

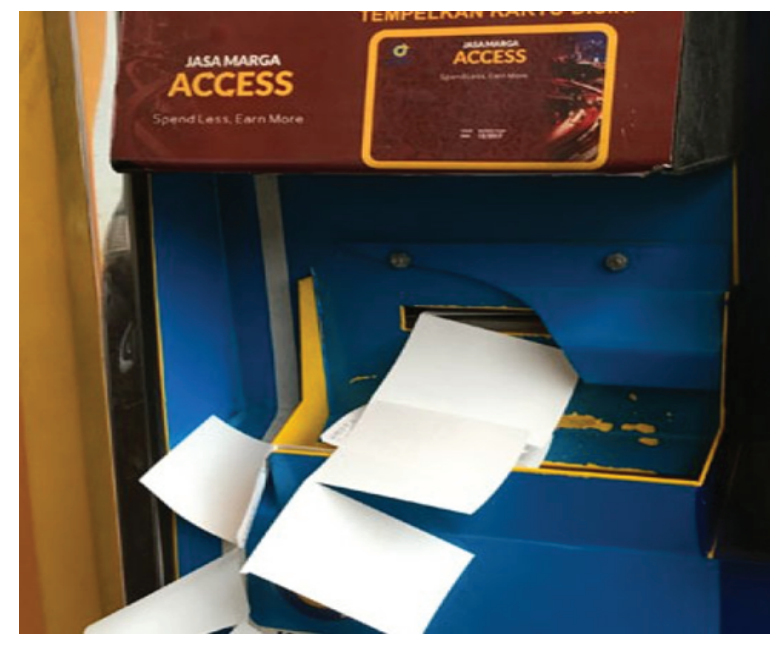

Figure 1: The unused received e-toll payment which blow everywhere.

Based on the statistical survey, many of the GTO customers are not requiring a paper as evidence of payment, as shown in Table 1. The statistical result shows that among all toll users, only $28 \%$ customer keeps the evidence of payment paper and $78 \%$ customer disposed the evidence. Furthermore, it can be seen from the graphic in Figure 2, that the number of the customer who is taking the receipt paper is lesser than the number of 
the customer who are not taking the receipt papers. Therefore, it is very reasonable that the straw paper waste is very easy to find scattered around toll payment substations.

TABLE 1: The result of the sampling data of the stopping time in the GTO station with the average of waiting time is $7.91 \mathrm{sec}$

\begin{tabular}{|c|c|c|c|c|c|}
\hline \multirow[b]{2}{*}{ Survey 1} & \multicolumn{2}{|c|}{ Retrieve Payment Receipt } & \multicolumn{2}{|c|}{ Do Not Retrieve Payment Receipt } & \multirow{2}{*}{$\begin{array}{c}\text { Total } \\
\text { Vehicles }\end{array}$} \\
\hline & & & & & \\
\hline GTO Gate A & 123 & $33 \%$ & 253 & $67 \%$ & 376 \\
\hline GTO Gate B & 152 & $34 \%$ & 301 & $66 \%$ & 453 \\
\hline GTO Gate C & 92 & $24 \%$ & 292 & $76 \%$ & 384 \\
\hline \multicolumn{6}{|l|}{ Survey 2} \\
\hline GTO Gate A & 53 & $26 \%$ & 152 & $74 \%$ & 205 \\
\hline GTO Gate B & 57 & $22 \%$ & 201 & $78 \%$ & 258 \\
\hline GTO Gate C & 71 & $28 \%$ & 183 & $72 \%$ & 254 \\
\hline \multicolumn{6}{|l|}{ Survey 3} \\
\hline GTO Gate A & 53 & $26 \%$ & 152 & $74 \%$ & 205 \\
\hline GTO Gate B & 73 & $30 \%$ & 167 & $70 \%$ & 240 \\
\hline GTO Gate C & 97 & $32 \%$ & 205 & $68 \%$ & 302 \\
\hline \multicolumn{6}{|l|}{ Survey 4} \\
\hline GTO Gate A & 83 & $29 \%$ & 199 & $71 \%$ & 282 \\
\hline GTO Gate B & 102 & $40 \%$ & 152 & $60 \%$ & 254 \\
\hline GTO Gate C & 57 & $25 \%$ & 172 & $75 \%$ & 229 \\
\hline
\end{tabular}

Based on that data, the use of paper payment received as evidence in the transaction still cannot be replaced by the electronic evidence. This is because the identity person data and the financial service account (bank) of that person is not integrated yet. Therefore, the electronics transaction evidence is not applicable. Besides, people are still trust and prefer the physic evident of the transaction [5].

\section{Research questions}

There are two important research questions have been proposed in this paper, namely firstly, how to deal with the proof of the transaction at the gate of the highway in the form of paper payment receipt to not be scattered everywhere. Secondly, what kind of design paper tray and design method can be reduced to unused paper's structures. 


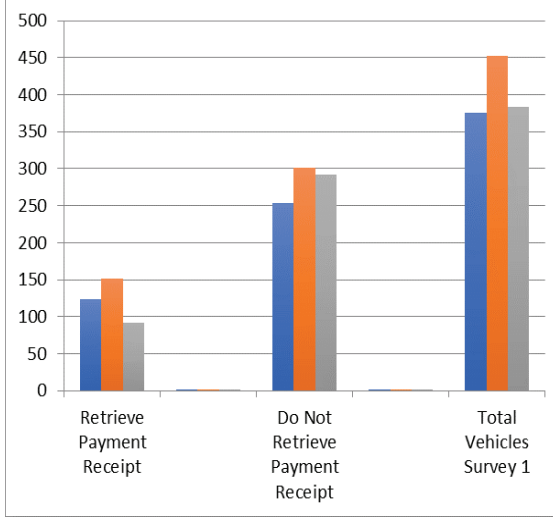

(a)

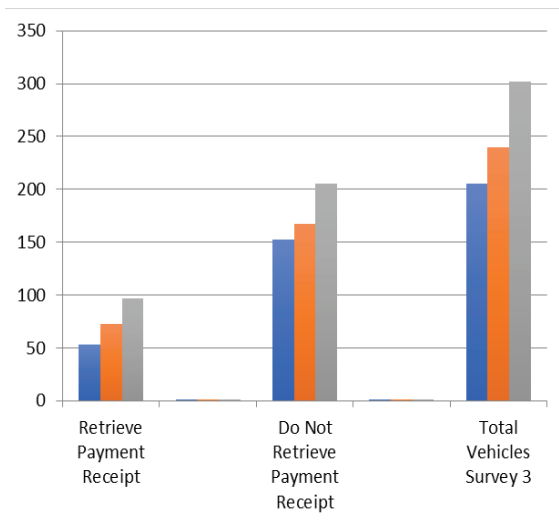

(c)

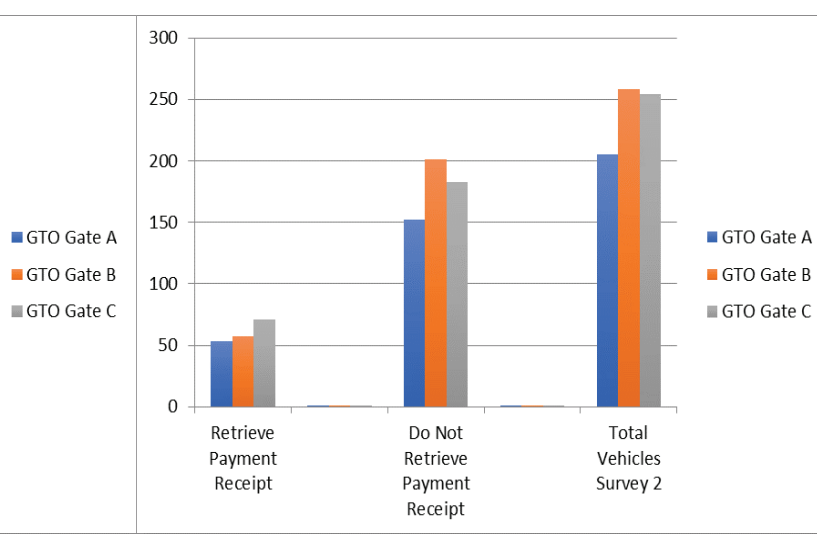

(b)

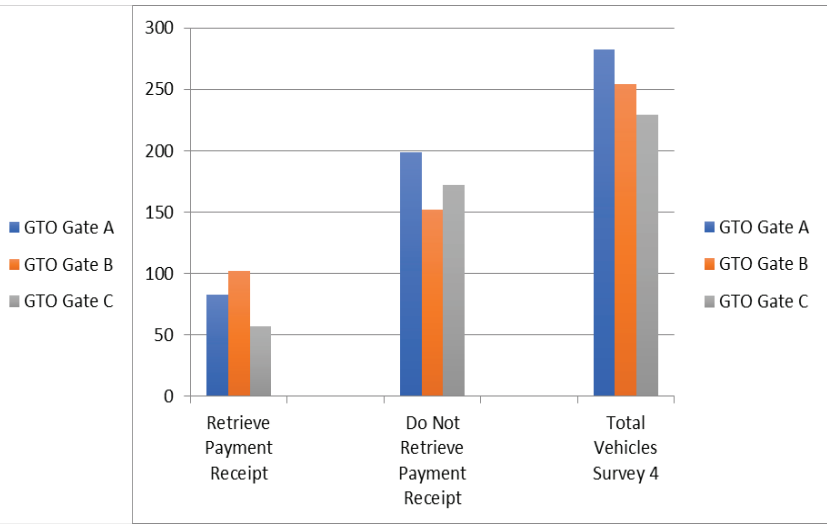

(d)

Figure 2: The comparison of the GTO customer which taken and not taken the payment receipt (a) survey 1 , (b) survey 2, (c) survey 3 , (d) survey 4.

\section{Purpose of study}

The objective of the study is to give the alternative solution in order to solve the problem in highway automatic gate (GTO). This problem happened from wasted paper payment receipt which sometimes scattered everywhere and unclean environment.

\section{Conceptual models}

In order to achieve the objective, there are many researches of a reducing paper receipt waste has been done, such as by giving the choice button whether the highway user willing to print the receipt or not. This idea is good, however there is still has a drawback, since the printing process will run when the button is pressed. This condition will generate additional time for the vehicle to stop a few seconds. This process is causing the received the paper payment can be suppressed because the customers who do not need the physical evidence will not get any. 
One other solution to solve the problem of garbage receipt at the toll gate that will be described in this research is by the approach of the mechanism of paper payment receipt, where the paper struck out of the printer machine will be offered to the driver and will move or rotate or shift to another place if not taken by the driver, and directly destroyed through an integrated paper shredder.

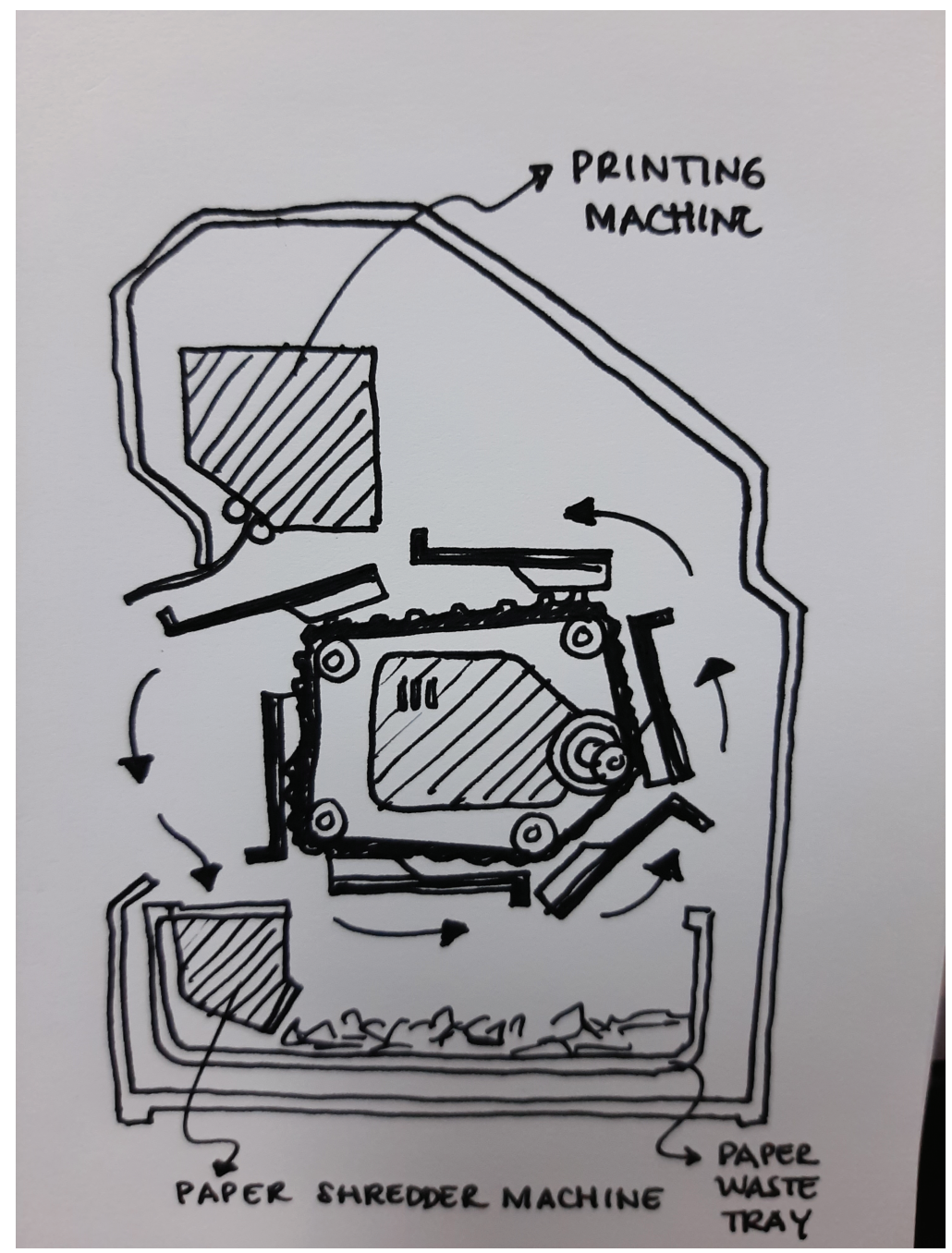

Figure 3: The paper tray mechanism concept of the proposed system.

Figure 3 shows the proposed paper tray system applied in this work. There are six important work steps of the proposed system. Firstly, the system starts with scanning the electronics e- toll card by the customer to the tollgate. In the second step, the toll-cost displayed on the toll-monitor, and received is printed. Then, it is released through the paper tray, with the holding paper tray to make the customer easy to hold and withdraw.

Up to this step, if the customer does not want to take the received paper after passing through the gate, then paper tray scrolls down automatically and the paper still hold of the paper tray. The next step is the paper tray will go mechanically to the 
Paper Shredder machine which will shred the toll received paper. In the last steps, the empty paper tray is ready to receive another paper toll received which are not taken by the customer by the next transaction. This process will continue repeating the same steps. This paper focus on the mechanical approaches, as compared to the ubiquitous system of toll payment that provides Radio Frequency Identification (RFID) on the other toll gate in Indonesia and abroad [6--8]. Furthermore, the mechanical versus automatic payment systems are within feasibilities studies in Indonesia, to be integrated as part of infrastructure, traffic management and transportation development toward smart cities all across Indonesia [9, 10].

Based on the comparative measurement results between the existing toll gate and the simulated results of the experimental tool carried out, as shown in Figure 4 and Figure 5 , respectively. It can be concluded, that the printed paper has the same print speed as the existing condition. However, the simulated result has the easiest way to pick up by the customer compare to the existing toll gate. The paper strap does not bind each other as it happened in the existing condition. In the simulation result, the paper which is not taken will be destroyed immediately when the paper tray has been in the position of removing the paper receipt into the position of destruction. Customers shortly after tapping and retrieving paper has a faster density than the existing condition where the loose paper is chaotic because it is tied together. Thus, technically and method, this system succeeded in giving solution in answer the problem that happened.

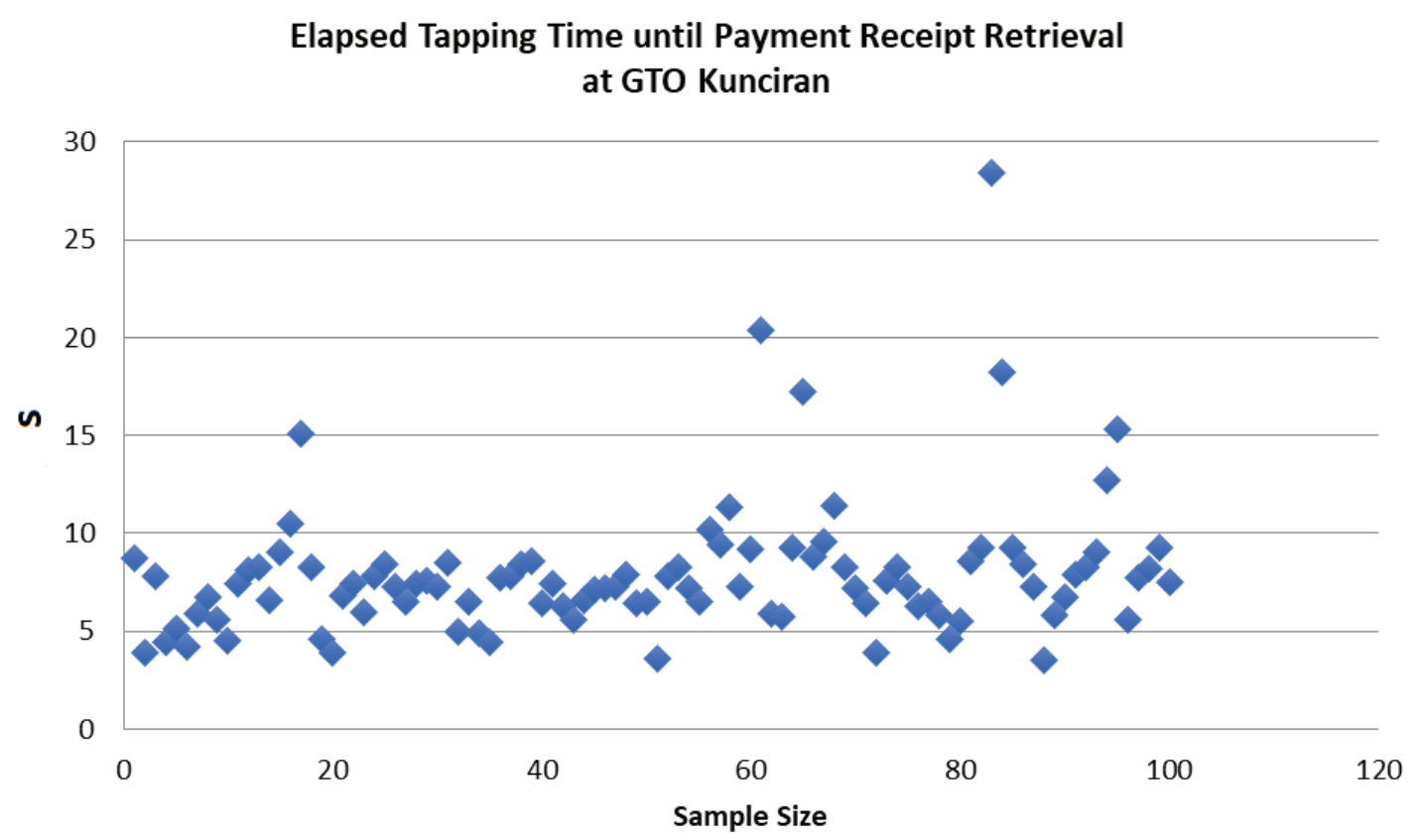

Figure 4: The sampling time data the taken paper receipt in toll Gate every transaction with waiting time of $7.91 \mathrm{~s}$ 


\section{Simulated Tapping time until Payment Receipt Retrieval at Experiment Time}

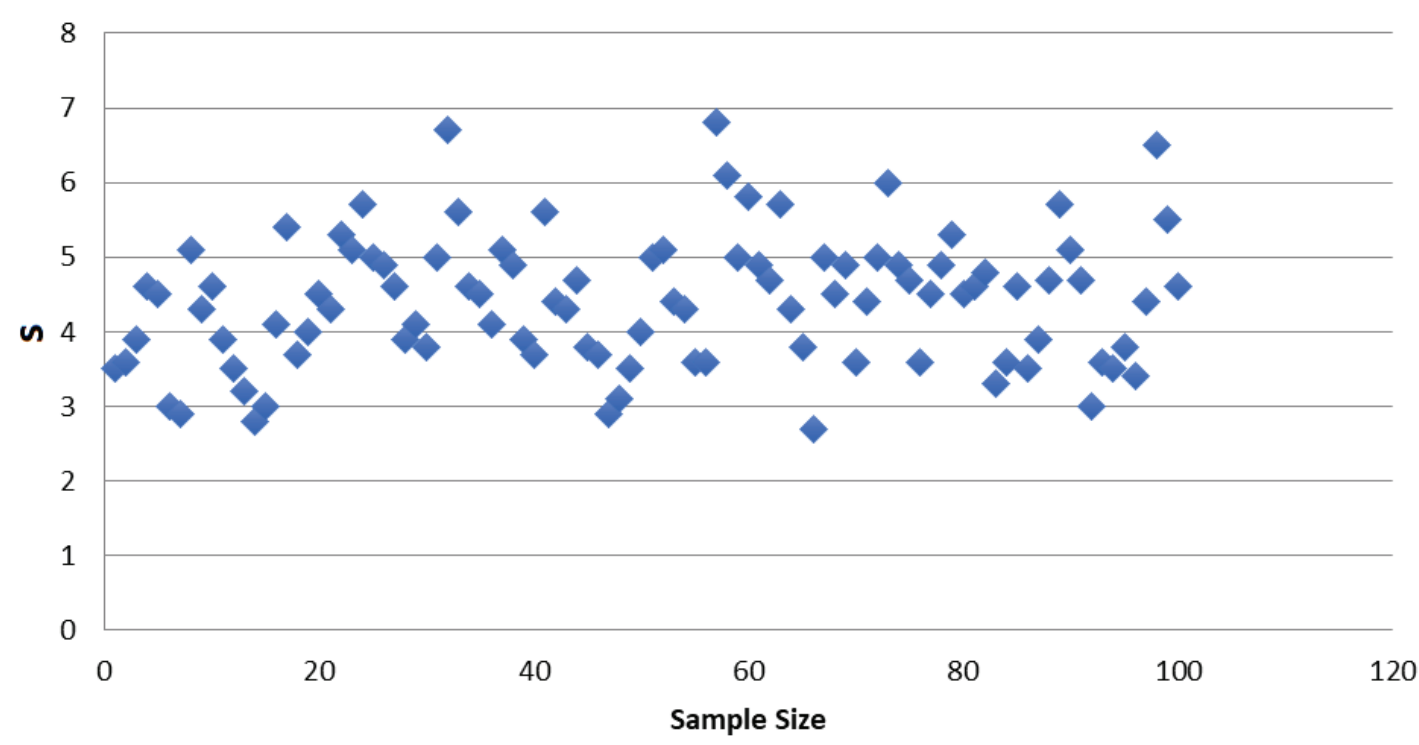

Figure 5: Time elapse for every transaction with a waiting time of $4.41 \mathrm{~s}$

\section{Conclusion}

The design concept of developing the system of payment system structure in GTO with receipt sending method is developed in this paper. The solution is simple, effective and easy to apply. This solution enables to solve the problem that often happens. The paper will not be wasted wherever not used, easy to reach if needed, and the results of waste from the paper can be directly recycled. Another benefit of this proposed system is also the officers at the machine location just simply monitor the capacity of waste generated regularly in the shredder. In addition, the waiting speed when the transaction can be shortened more significantly.

\section{References}

[1] World Economic Forum. ASEAN 4.0: what does the fourth industrial revolution mean for regional economic integration?. World Economic Forum [Online] from https://www.weforum.org/whitepapers/asean-4-0-what-does-the-fourth-industrialrevolution-mean-for-regional-economic-integration (2017). [Accessed on 8 June 2018]

[2] Powell JH. Innovation, technology, and the payment system. BIS central bankers' speeches [Online] from https://ideas.repec.org/p/fip/fedgsq/940.html 
(2017). [Accessed on June 2018]

[3] Fatkhurrahman MA, Syafei WA, Drajat. Perancangan prototipe sistem gerbang tol cerdas berbasis rfid dan notifikasi pembayaran via social messenger [Designing prototypes of rfid-based smart toll gate systems and notification of payments via social messenger]. Transient, 2017; 7(4), 690--697. [in Bahasa Indonesia]. https:// ejournal3.undip.ac.id/index.php/transient/article/view/18887/0

[4] Nandhini S, Premkumar P. Automatic toll gate system using advanced rfid and gsm technology. International Journal of Advanced Research in Electrical, Electronics and Instrumentation Engineering 2014; 3(5):13002--13007. https://www.ijareeie.com/ upload/2014/november/26H_Automatic.pdf

[5] Yuliastuti D. 3 era perkembangan digital payment di Indonesia [3 era of digital development payment in Indonesia]. Digination.id [Online] from https://www. digination.id/read/01513/3-era-perkembangan-digital-payment-di-indonesia (2017). [Accessed on 27 July 2018]. [in Bahasa Indonesia].

[6] Cermati.com. Bayar tol wajib gunakan e-money berlaku Oktober 2017 [Highway payment must using e-money start from October 2017]. Cermati.com (2017) [Online] from https://www.cermati.com/artikel/bayar-tol-wajib-gunakan-e-moneyberlaku-oktober-2017. [Accessed on 27 July 2018]. [in Bahasa Indonesia].

[7] Nandhini S, Premkumar P. Automatic toll gate system using advanced RFID and GSM technology. International Journal of Advanced Research in Electrical, Electronics and Instrumentation Engineering 2014; 3(5):13002--13007. https://www.ijareeie.com/ upload/2014/november/26H_Automatic.pdf

[8] Desriandini NF. (2015). Simulasi Gerbang Tol Otomatis berbasis Arduino Uno menggunakan RFID. Yuliastuti D. (2017). 3 era perkembangan digital payment di Indonesia [3 era of digital development payment in Indonesia]. Digination.id [Online] from https://www.digination.id/read/01513/3-era-perkembangan-digital-payment-diindonesia (2017). [Accessed on 27 July 2018].

[9] Mithya V, Dharani KV, Nivetha A, Praveen RG, Roshel IM. Smart highway toll collection system. International Journal of Innovative Technology and Exploring Engineering 2019; 8(5):418--421. https://webcache.googleusercontent.com/search?q= cache:nVBRec9c8pgJ:https://www.ijitee.org/wp-content/uploads/papers/v8i5s/ ES3456018319.pdf + \&d=1\&hl=en\&ct=clnk\&gl=id

[10] Gade D. ICT based smart traffic management system "iSMART" for smart cities. International Journal of Recent Technology and Engineering 2019; 8(3):1000-1006 https://www.semanticscholar.org/paper/ICT-Enabled-Smart-Parking-System\%3A-Smartpark-for-Gade/013d0e2b59e799fe1779256790b1916549f45040 